\title{
A Note on an ECM asymmetry in Spanish*
}

\author{
Lorena Castillo Ros
}

Centre de Lingüística Teòrica / Universitat Autònoma de Barcelona

lorena.castilloros@gmail.com

\begin{abstract}
This paper discusses an asymmetry in Spanish ECM structures whereby NP passivization improves if the embedded clause is a non-infinitive. The facts are accounted for by assuming that structural Case can only be assigned once within a relevant domain (a phase; cf. Chomsky 2000, 2001). This raises non-trivial questions about Case competition and Case resistance facts, opening new perspectives on the study of the Case/agreement systems and their parametric variation.
\end{abstract}

Keywords: Case Theory, Case competition, ECM, phase, Spanish.

\section{Table of Contents}
1. Introduction
4. A Case competition approach
2. ECM: background data
3. ECM in Spanish: the asymmetry
5. Conclusion
References

\footnotetext{
* A version of this paper was presented at the XLVI Simposio of the Sociedad Española de Lingüistica, held at the CSIC (Madrid), 24-27 January 2017. I would like to thank the audience for questions and discussion. Special thanks go to Ignacio Bosque, José M. Brucart, Ricardo Etxepare, Ángel Gallego, M.Lluïsa Hernanz, and Juan Uriagereka for comments and suggestions. This research has been partially supported by the Ministerio de Economía y Competitividad (FFI2014-56968-C4-2-P) and the Institució Catalana de Recerca i Estudis Avançats (ICREA Acadèmia, Ángel Gallego). Usual disclaimers apply.
} 


\section{Introduction}

ECM phenomena (cf. Lasnik \& Saito 1999, Lasnik 2001, 2002, 2003, and references therein) have not been a main focus of interest in the literature of Spanish. Instead, attention has been paid to specific constructions, headed by causative and perception predicates (cf. Treviño 1994, Hernanz 1999, Guasti 2005, Torrego 2010, among others). The reason can probably attributed to well-known asymmetries between Romance and English ECM (cf. Kayne 1981, 2004, Uriagereka 1988, 2006, Gallego 2009, 2010), for only the latter allow predicates of the believe and want type in ECM contexts.

This paper does not intend to cover those facts, along with the general questions that ECM raises. Instead, I would like to concentrate on the asymmetry illustrated in (1) and (2), which features a raising-to-object situation in Spanish: ${ }^{2}$
a. Alguien vio [тр a los policías entrar en los colegios ] someone saw ACC the policement get-into in the schools 'Someone saw the policemen get into the schools'
b. *?Los policías fueron vistos [тр $\mathrm{t}_{\text {los policías }}$ entrar en los colegios ] the policemen were seen get-into in the schools 'The policement were seen to get into the school'
a. Alguien vio [тр a los policías entrando en los colegios ] someone saw ACC the policement getting-into in the schools 'Someone saw the policemen getting into the schools' the policemen were seen getting-into in the schools 'The policement were seen getting into the school'
b. Los policías fueron vistos [те $t_{\text {los policías }}$ entrando en los colegios ]

As can be seen, raising of the NP los policias (Eng. 'the policemen') seems to be subject to the morphological nature of the embedded verb: whereas gerunds (like participles and other non-verbal predicates) allow rising, infinitives yield deviance. I would like to suggest an approach to the facts that capitalizes on the fact that the NP and the embedded clause belong to the same Case assignment domain. This pressuposes that clauses can receive Case under certain circumstances (pace Stowell 1981), an assumption I would like to relate to the more nominal status of Romance complementizers (cf. Picallo 2002, Manzini \& Savoia 2003, Torrego \& Uriagereka 1992, Plann 1982). In particular, I argue that structural Case can only be assigned once withing a given domain (a phase; cf. Chomsky 2000, 2001): In the cases that concern us, it is either the NP or the embedded clause that gets structural accusative. I will take that to account for the fact that NPs resist passivization with an infinitive, whose nominal nature makes it a bona fide competitor for Case assignment. ${ }^{3}$

\footnotetext{
${ }^{2}$ As the English translation reveals, perception verbs select vPs, not TPs, as the presence of to is ruled out. Intriguingly, to is mandatory under passivization. Similar facts have been noted for Peruvian Spanish (cf. Montalbetti 1999). Due to space limitations, I do not address this asymmetry here, which is handled by Hornstein et al. (2006) within Chomsky's Probe-Goal framewrok (cf. Chomsky 2000, 2001).

${ }^{3}$ Details of implementation aside, the idea is compatible with the possibility that Probe-Goal relations are restricted to one per domain (cf. Ormazabal \& Romero 2007). For similar observations, cf. Marantz (1991).
} 
Discussion is divided as follows: section 2 introduces the technical assumptions I make and the Spanish data; in section 3 I explore the idea that NPs and embedded clauses compete for Goal-hood; finally, section 5 summarizes the main conclusions.

\section{ECM in Spanish: the asymmetry}

In this paper I will assume the standard Case distinction proposed by Chomsky (1986), according to which there are two types of Case: structural and inherent. Following Chomsky $(2000,2001)$, I further assume that structural Case is assigned by means of a Probe that contains uninterpretable $\phi$-features, whereas inherent Case is dependent upon Merge (External Merge, EM; cf. Chomsky 2004). This would account for the fact that only the latter is subject to semantic effects (of the theta-theory type): ${ }^{4}$

(3) Structural Case: Probe-Goal dependency

Inherent Case: Merge dependency

In recent papers, Chomsky has addressed the reason why raising-to-subject / object (RtS and RtO, henceforth) take place. In the case of raising-to-object, Chomsky assumes that the process is mandatory for the same reason it is in raising-to-subject cases (EPP effects): a labeling conflict (cf. Chomsky 2013, 2015, Gallego 2017). RtO is thus generalized to both embedded (see (4a)) and non-embedded (see (4b)) clauses:
a. Nobody [vp $\mathrm{t}_{\text {Nobody }}\left[\operatorname{saw}\left[\mathrm{vP}\right.\right.$ agent $\left.\mathrm{K}\left[\mathrm{Vt}_{\mathrm{agent}} \mathrm{K}\right]\right]$ ] ]
b. Nobody [vP $t_{\text {Nobody }}\left[\operatorname{saw}\left[\mathrm{vP}\right.\right.$ agent $\mathrm{K}\left[\mathrm{V}\left[\mathrm{t}_{\mathrm{agent}} \mathrm{K}\right.\right.$ pass the baseline test $\left.\left.\left.]\right]\right]\right]$

English ECM cases covers different types of predicates: epistemic verbs of the believe type, volitive verbs of the want type, perception verbs of the see type, and causative verbs. Romance languages cannot display ECM with believe and want (cf. Kayne 1981, 2004, and references therein), but they can with causatives and perception predicates:
a. Joy vio [ $\mathrm{a} \quad \mathrm{K}$ acompañar a Deckard ] Joy saw.3sg ACC K go-with.inf ACC Deckard 'Joy saw K go with Deckard'
b. Joy vio [a $\quad \mathrm{K}$ acompañando a Deckard ] Joy saw.3sg ACC K go-with.ger ACC Deckard 'Joy saw K going with Deckard'
c. Joy vio [ [ $\mathrm{K}$ acompañando por Deckard ] Joy saw.3sg ACC K accompany.p.part. by Deckard 'Joy saw K accompanied by Deckard'

In the case of causatives, the embedded verb can only be in infinitival form, but perception predicates can select infinitives, gerunds and participles. Interestingly,

\footnotetext{
${ }^{4}$ There is another distinction just related to the non-structural Case: lexical and inherent (Woolford 2006). However, that is not relevant to what I will discuss in this paper.
} 
passivization reveals an unexpected asymmetry: only gerunds and participles readily allow for the ECM-ed NP to undergo RtS. ${ }^{5}$
a. *?K fue visto [ $t_{\mathrm{K}}$ acompañar a Deckard ]
$\mathrm{K}$ was.3sg seen go-with.inf ACC Deckard
'K was seen to go with Deckard'
b. $K$ fue visto [ $t_{K}$ acompañando a Deckard]
$\mathrm{K}$ was.3sg seen go-with.ger ACC Deckard
'K was seen to go with Deckard'
c. $\mathrm{K}$ fue visto [ $\mathrm{t}_{\mathrm{K}}$ acompañado por Deckard]
$\mathrm{K}$ was.3sg seen go-with.p.part by Deckard
'K was seen accompanied by Deckard'

(Spanish)

Although the facts are clear, it is not immediately obvious what they follow from. In all the examples in (5) above, the subject NP seems to receive accusative Case from matrix $\mathrm{v}^{*}$. This is shown in (7), where the embedded subject can be replaced by an accusative clitic (lo, Eng. 'him'):

$$
\begin{aligned}
& \text { Joy lo vio [ } \mathrm{t}_{\mathrm{lo}}\{\text { acompañar/acompañando/acompañado }\}\{\mathrm{a} / \text { por }\} \text { Deckard ] } \\
& \text { Joy CL.acc saw go-with.inf./gerund/p.part. to by Deckard } \\
& \text { 'Joy saw him go with/going with/accompanied by Deckard' }
\end{aligned}
$$

This said, the fact that RtS is worse in (6a) tells us that the ECM-marked NP is truly accusative only in non-infinitive structures (gerund and participles). ${ }^{6}$ Taken together, these data raise, at the very least, two questions:
a. What Case does the NP within the embedded clause receive?
b. Does the embedded clause receive Case too?

I just offered a way to go about question (8a), but a full, explanatory, answer is necessarily connected to the answer we provide to question (8b). Departing from Stowell (1981), I assume that embedded clauses may receive Case (cf. Picallo 2002, Manzini \& Savoia 2003, Torrego \& Uriagereka 1992, Plann 1982). More precisely, I would like to submit that clauses, like nominals, can receive both structural and inherent Case. It is precisely this choice, which I relate to the infinitive / non-infinitive distinction, that determines the Case of the NP, and thus RtS.

\section{A Case competition approach}

I have just argued that clauses and NPs are potential Goals in Chomsky's (2000, 2001) framework, which is tantamount to saying that they can receive structural of inherent Case. Here I would like to defend the claims in (9):

\footnotetext{
${ }^{5}$ For what it's worth, RtS is also possible if the verb is replaced by an AdJP or a PP. I put aside these cases, focusing on clausal objects instead.

${ }^{6}$ If correct, then the accusative Case in (6a) would be inherent, an option that has been discussed by Torrego (1998) in the context of DOM phenomena.
} 
(9) - If embedded clause receives structural Case, then the NP receives nonstructural Case.

- If the NP receives structural Case, then embedded clause receives nonstructural Case.

What (9) is telling us is that, unlike inherent Case, structural Case assignment is limited within a phases. This seems to be compatible with the fact that there can be $n$ applications of MERGE between Ps and NPs phase internally, while Probe-Goal dependencies are limited to one-module Multiple Agree or Covaluation, which basically collapse multiple Goals into one for the purposes of AGREE (cf. Hiraiwa 2005, López 2007).

In line with what (9) says, here I would like to defend the idea that ECM structures can be treated as a Multiple Object Construction (MOC). In MOCs, only one of the objects can receive structural Case; the other gets non-structural Case. Ormazabal \& Romero (2007) call this the Object Agreement Constraint (OAC), which I will adopt. The definition of OAC is given in (5):

\section{(10) Object Agreement Constraint (OAC)}

If the verbal complex encodes object agreement, no other argument can be licensed through verbal agreement

[from Ormazabal \& Romero 2007: 336]

As the data in (5) and (6) show, infinitival clauses must be different from gerund and participle ones. I suggest this is structurally encoded, in the sense that infinitival clauses are bigger: at least a TP. Given their regular status, TPs need to get Case, just like any other CP does. This is reinforced by the "nominal" status of complementizers, especially in Romance languages. Consider (11):

(11) Eso provocó [CP (el) que los problemas empeorasen ] that made.3sg the that the problems get-worse.3pl

(Spanish) 'That made problems get worse'

The example in (11) shows that CPs can display nominal morphology (a definite article). The same holds for infinitives, but crucially not for gerunds and participles:
a. Me preocupa [(el) tener tantos deadlines ]
CL.dat worry.3sg the have.inf so-many dealines
'Having so many deadlines worries me'
b. [ (*El) teniendo tantos deadlines ], estoy preocupado
the having so-many deadlines be.1sg worried
'Having so many deadlines, I'm worried'
c. $[(* \mathrm{El})$ resueltos los problemas $]$, me fui
the solved the problems CL left.1sg
'Once the problems were solved, I left'

According to all I have said so far, we need two things to happen. One, TPs must be visible to matrix $\mathrm{v}^{*}$ to get Case-structural in Spanish, but inherent in English, according to the key asymmetry in (13): 
(13) a. Agent K was seen $\{$ to pass/passing $\}$ the baseline test

b. El agente $\mathrm{K}$ fue visto $\left\{?^{*}\right.$ superar/superando $\}$ pasar el test de control

Two, NPs must not be able to receive Case in Spanish. I assume this is what happens, as the highest copy of the chain is above $\mathrm{v}^{*}$, which makes it invisible to this Probe. In English, this is not the case, due to the raising-to-object process: the DP raises to matrix SPEC-V (cf. Lasnik \& Saito 1999, Lasnik 2001, 2002, 2003), a position visible to $\mathrm{V}^{*}$. In the case of Spanish ECM, I claim that the NP moves to SPEC- $\mathrm{v}^{*}$, the landing site of DOM objects (cf. Torrego 1998). As a result, the chain of the NP is not visible to $\mathrm{v}^{*}$, only the TP is. This can be seen in (14a) and (14b):
a. $\left[\mathrm{v}^{* \mathrm{P}} \quad \mathrm{v} *\left[\mathrm{vP} \underline{\mathbf{N P}} \mathrm{V}\left[\mathrm{TP} \mathrm{t}_{\mathrm{NP}} \mathrm{T}\left[\ldots \mathrm{t}_{\mathrm{NP}}\right]\right]\right]\right]$
ENGLISH
b. $\left[\mathrm{v}^{* \mathrm{P}} \underline{\mathbf{N P}} \mathrm{v} *\left[\mathrm{vP} \mathrm{t}_{\mathrm{NP}} \mathrm{V}\left[\mathrm{TP} \mathrm{t}_{\mathrm{NP}} \mathrm{T}\left[\ldots \mathrm{t}_{\mathrm{NP}}\right]\right]\right]\right]$
SPANISH

Since a NP requires Case, it is assigned non-structural Case by means of the DOM strategy. This may suggest that this instance of DOM is close enough to that discussed in Kayne's (2004) analysis of causative structures. If so, the DOM marker would be some kind of prepositional complementizer, as argued by Ordóñez \& Roca (2018) on independent grounds.

In the case of gerunds and participles, I take it that they are some kind of predicative projection. To be specific, I will treat them as prepositional, following ideas of Mateu (2002) and Gallego \& Hernanz (2012). What is important here is that prepositional phrases do not need Case. This makes them immune to Ormazabal \& Romero's OAC.
a. $\left[v^{* P} v^{*}\left[\mathrm{vP} V\left[N P \underline{C}\left[\ldots \mathrm{t}_{\mathrm{NP}}\right]\right]\right]\right]$
b. $\left[\mathrm{v}^{* \mathrm{P}} \mathrm{v}^{*}\left[\mathrm{vP} \mathrm{V}\left[\mathrm{NP} \underline{\mathbf{P}}\left[\ldots \mathrm{t}_{\mathrm{NP}}\right]\right]\right]\right]$
INFINITIVAL GER./PAR.

Overall, the sketched solution provides a way to account for the fact that infinitivals, unlike gerunds and past participles, get structural Case in Spanish, making it impossible for ECM subjects to undergo RtS in this language (in passives).

\section{Conclusion}

This paper has investigated an asymmetry that concerns the subjects of ECM predicates in Spanish. As I have shown, subjects of infinitival predicates resist passivization, unlike that of gerunds and participles, a situation I have addressed by making three key assumptions: (i) infinitives are structurally different to gerunds and participles (they are more nominal or less prepositional/predicative), (ii) TPs are closer to matrix $\mathrm{v}^{*}$ than the ECM subject, which makes them get Case (by locality metrics), and (iii) structural Case can only be assigned once within the same phase. I believe there is empirical evidence to take (i) and (iii) to be universal. This is not the case of (ii), which provides a way to address the parametric difference between Spanish and English illustrated in (13). Further questions remain to be answered about the nature of Case and the parametric nuances that concern the behavior of objects cross-linguistically. If what I have suggested in the previous pages is on track, the connection between ECMs, MOCs, DOM and DOCs deserves further research (Boeckx \& Hornstein Rezac 2013, just like the variable status of structural and inherent Case does 


\section{References}

Boeckx, Cedric and Norbert Hornstein. 2005. "A gap in the ECM paradigm”. Linguistic Inquiry 36: 437-441. https://doi.org/10.1162/0024389054396926

Chomsky, Noam. 1986. Knowledge of language. Its nature, origin, and use. New York: Praeger.

Chomsky, Noam. 2000. "Minimalist inquiries: The framework". In R. Martin et al. (eds.), Step by step. Essays on minimalist syntax in honor of Howard Lasnik, 89155. Cambridge, MA: MIT Press.

Chomsky, Noam. 2001. "Derivation by phase". In M. Kenstowicz (ed.), Ken Hale: A life in language, 1-52. Cambridge, MA: MIT Press.

Chomsky, Noam. 2004. "Beyond explanatory adequacy". In A. Belletti (ed.), Structures and beyond. The cartography of syntactic structures (vol. 3), 104-131. Oxford, NY: Oxford University Press.

Chomsky, Noam. 2013. "Problems of Projection". Lingua 130: 33-49. https://doi.org/10.1016/j.lingua.2012.12.003

Chomsky, Noam. 2015. "Problems of Projection. Extensions". In E. di Domenico et al. (eds.), Structures, Strategies and Beyond, 1-16. Amsterdam: John Benjamins.

Gallego, Ángel J. 2009. "Defective C-T in Romance". Probus 21: 163-216. https://doi.org/10.1515/prbs.2009.006

Gallego, Ángel J. 2010. Phase Theory. Amsterdam: John Benjamins. https://doi.org/10.1075/la.152

Gallego, Ángel J. 2017. "The EPP in Labeling Theory: Evidence from Romance". Syntax 20.4: 384-399. https://doi.org/10.1111/synt.12139

Gallego, Ángel J. and M.Lluïsa Hernanz. 2012. “Tipos de tiempo defectivo". In E. Ridruejo Alonso et al. (edd.), Tradición y progreso en la lingüística general, 197-215. Valladolid: Universidad de Valladolid.

Guasti, M. Teresa. 2005. "Analytic causatives". In M. Everaert and H. van Riemsdijk (eds.), The Blackwell Companion to Syntax, 142-172. Oxford: Blackwell.

Hernanz, Maria Lluïsa. 1999. "El infinitivo". In I. Bosque and V. Demonte (eds.), Gramática descriptiva de la lengua española, 2197-2356. Madrid: Espasa.

Hiraiwa, Ken. 2005. Dimensions of symmetry in syntax: Agreement and clausal architecture. PhD dissertation, MIT.

Hornstein, Norbert, Ana Maria Martins and Jairo Nunes. 2006. "Infinitival Complements of Perception and Causative Verbs: A Case Study on Agreement and Intervention Effects in English and European Portuguese". In Nina Kazanina et al. (eds.), University of Maryland Working Papers in Linguistics 14, 81-110. College Park, MD: UMWPiL.

Kayne, Richard. 1981. "On certain differences between French and English”. Linguistic Inquiry 12: 349-71.

Kayne, Richard. 2004. "Prepositions as Probes". In A. Belletti (ed.), Structures and Beyond. The Cartography of Syntactic Structures (vol. 3), 192-212. Oxford, NY: Oxford University Press.

Lasnik, Howard. 2001. "Subjects, objects, and the EPP". In W. Davies and S. Dubinsky (eds.), Objects and other subjects, 103-121. Dordrecht: Kluwer. https://doi.org/10.1007/978-94-010-0991-1 5

Lasnik, Howard. 2002. “Clause-mate conditions revisited”. Glot International 6: 94-96. 
Lasnik, Howard. 2003. Minimalist investigations in linguistic theory. London: Routledge.

Lasnik, Howard and Mamoru Saito. 1999. "On the subject of infinitives”. In Minimalist analysis, 7-24. Oxford: Blackwell.

López, Luis. 2007. Locality and the architecture of syntactic dependencies. New York: Palgrave.

Manzini, Rita and Leonardo Savoia. 2003. "The Nature of Complementizers". Rivista di Grammatica Generativa 28: 87-110.

Marantz, Alec. 1991. "Case and licensing". In G. Westphal et al. (eds.), Eastern States Conference on Linguistics, 234-253. Ithaca, NY: Cornell University, Cornell Linguistics Club.

Mateu, Jaume. 2002. Argument structure: Relational construal at the syntax-semantics interface. $\mathrm{PhD}$ Dissertation, UAB.

Montalbetti, Mario. 1999. "Spanish Passivized Datives: The Relevance of Misanalysis". In K. Johnson and I. Roberts (eds.), Beyond Principles and Parameters, 133-144. Kluwer: Dordrecht. https://doi.org/10.1007/978-94-011-4822-1_5

Picallo, Carme. 2002. "Abstract agreement and clausal arguments". Syntax 5: 116-147. https://doi.org/10.1111/1467-9612.00049

Ordóñez, Francisco and Francesc Roca. 2018. "Differential Object Marking (DOM) and clitic subspecification in Catalonian Spanish". In Á.J.Gallego (ed.), The syntactic variation of Spanish dialects. Oxford: Oxford University Press.

Ormazabal, Javier and Juan Romero. 2007. "The Object Agreement Constraint". Natural Language and Linguistic Theory 25: 315-347. https://doi.org/10.1007/s11049-006-9010-9

Rezac, Milan. 2013. "Case and Licensing: Evidence from ECM + DOC". Linguistic Inquiry 44: 299-319.

https://doi.org/10.1162/ling_a_00129

Stowell, Tim. 1981. The origins of phrase structure. PhD Dissertation, MIT.

Torrego, Esther. 1998. The Dependencies of Objects. Cambridge, MA: MIT Press.

Torrego, Esther and Juan Uriagereka. 1992. "Indicative dependents". Ms., UMass Boston/UMD.

Treviño, Esthela. 1994. Las causativas del español con complemento infinitivo. México: El Colegio de México.

Uriagereka, Juan. 1988. On Government. PhD Dissertation, UConn.

Uriagereka, Juan. 2006. "Complete and partial Infl”. InC. Boeckx (ed.), Agreement systems, 267-298. Amsterdam: John Benjamins. https://doi.org/10.1075/la.92.12uri

Woolford, Ellen. 2006. "Lexical case, inherent case, and argument structure". Linguistic Inquiry 37: 111-130. https://doi.org/10.1162/002438906775321175 